\title{
Influence of English Language on the Cultural Identity of Learners
}

\author{
* Muhammad Ajmal, Assistant Professor \\ ** Dr. Fouzia Ajmal, Assistant Professor (Corresponding Author) \\ *** Dr. Sadaf Zamir Ahmed, Assistant Professor
}

\begin{abstract}
The current research endeavored to find out the influence of English language learning on the Cultural Identity of Pakistani secondary school students. For purpose of investigation, 60 students of secondary level from private schools were selected for the data collection. A questionnaire consisting of close-ended questions was delivered to the participants to be filled in; the study had applied a quantitative method for data analysis. The result indicates that learning the English language has both positive and negative effects on student's Cultural Identity (CI). Learning the English Language is important, being the language of technology and lingua franca. But language never comes alone; it comes with its culture. The school students are getting affected by Western culture. This study has significant implications for further research work in this area.
\end{abstract}

Keywords: $\quad$ English Language, Cultural Identity, Secondary Level, Affects

Introduction

For hundreds of years, anthropologists and linguists are studying the effect of language on culture, as well as how language influences society. The existence of the culture in different communities is always supported by the specific means of communication of people, i.e. langue and language. Language is a set of symbols used primarily for communication purposes. Language does not end in the meaning or use of culture-related words. Words themselves represent history, beliefs, the culture of their origin which is partly acquired and mostly inherited and also learned to be used properly in relevant situations. The relationship between language and culture is undetermined and deeply rooted. Language is used to communicate culture and to maintain cultural links. Norton in 2000 said that the language learners use the language for conversation and communication, but in fact, the language learning is influencing their viewpoint about the world also (Anbreen, 2014).

Different researches are available to investigate the impact of ESL on learners in a non-native context, particularly in postcolonial cultures where English is taught as a second or third language. The English language is commonly accepted as an international language and it is essential to get aware of its use. To learn English as a second language, it is important to understand the culture in which the language is born. Language and culture are often said to be two inseparable elements of society one might believe that language is nothing without culture and a language, there is no culture. It is a fact that language is not an individual expression" but a social and cultural phenomenon'. A man adopts the culture of a society, its modes of thought and action through language, their convictions, and values. "Through his membership of society and his occupation of social roles, human beings become a personality" (Nawaz, 2012, p.7).

\section{Research Objectives}

The main objectives of this study are:

i. To investigate the effects of Cultural Identity $(\mathrm{CI})$ of students due to the increasing demand for English Language (EL).

ii. To determine the linguistics patterns which affect students' Cultural Identity (CI).

iii. To explore the influence of EL on the perception of students CI?

* Department of English, University of Lahore, Pakistan Email: muhammad.ajmal2@ell.uol.edu.pk

** Department of Education, International Islamic University Islamabad Pakistan

Email: fouzia.ajmal@iiu.edu.pk

*** Department of Humanities, Education and Psychology, Air University, Islamabad, Pakistan

Email: sadaf.zamir@mail.au.edu.pk 


\section{Literature Review}

This section explores the great efforts of different researchers who have devoted themselves to the study of CI of students and their relationship with language learning. According to Hofstede (2003), The Culture is the fountain of a civilized society and progress over time with its values and norms. It is not a fixed concept it changes for many reasons (Spencer-Oatey, 2012).

Pakistani culture is very diverse because ethnic groups have distinct cultural values and standards. Because the area now known as Pakistan has been invaded by many different countries or factions of people in the past among those invaders, The British were the most prominent. Communication is a great tool that connects the world's people and turns the world into a global village. These are some pieces of evidence proving that communication is society's most important factor. Media, the internet, and others prove it. Ormrod (1995) suggests that it is possible to describe language as a basic form of communication. Language is learned through behaviors such as thinking, acting, and feelings, according to behaviorist (The Origin of Language: English Language Essay, 2016).

Language Identity is reflection on as 'the alleged or potentially ascribed connection between one's self-appreciation and a methods for correspondence which may be known as a language (for example English) a tongue (Rekhta) or a sociolect (for example legal counselor talk) (Razmeh, 2015). However, for this study, 'identity' refers to, alludes to, How an individual gets their relationship to the world, how that relationship is worked across existence, and how the individual comprehends opportunities for what's to come for the future.

According to Buch (2009); 'Identity shifts happen during the obtaining of another dialect and that the character shifts are firmly related to social character' (Razmeh, 2015, p. 70). "Identity shifting happens when one can quickly move character as indicated by the phonetic and social setting" (Hall, 2002, p. 242). Ochs wrote in his book that Social identity is an assortment of social people, including societal position, jobs, connections, and institutional and other relevant characters that might be endeavored to guarantee during social life (Ochs, 1993). Hayati believes that 'Since there are different definitions of culture, it is better to first say our definition of polestar so that we understand its language relationship. Culture is part of the cognition that goes into the common mentality or society of the people or the lives of universal people.

Pakistani culture is very diverse. It is in matters of their dress food and religion among the various ethnic groups and also differs from Islamic practices in pre - Islamic customs. Pakistan is South Asia's first region to be fully influenced by Islam and developed Islamic identity. If an individual can speak with an even somewhat of a British English accent, he or she is considered educated and somewhat superior! Unfortunately, we have adopted English from the day first not Urdu.

In Pakistan, two distinct education systems are identified primarily in terms of the educational medium, i.e. Medium of English (English Medium) and medium of Urdu (Urdu Medium). The English medium schools are privately owned and serviced by the upper class as well as some middle-class sections. On the other hand, Urdu medium schools are primarily public sector schools that cater to lower-income groups and offer free education as well as other incentives such as free textbooks (at least at the primary level). Private schools provide elite children with ' quality ' education through the English medium in highly resourced classrooms (Shamim, 2005, p. 16). A student with his own identity and culture enters the classroom. The student must also learn the culture of the foreign language when learning a foreign language (Huany, 2019, p. 76).

\section{Research Methodology}

The study involves a quantitative method and a survey was conducted.

\section{Population and Sampling}

The participants were the secondary students of Unique Public School and Bahria School (Bahria town Lahore branch). Male and female participants were treated equally in acquiring information so that in regards to data collection gender discrimination could not affect the samples.

The probability sampling technique (simple random sampling) was used in this study. The purpose of selecting this sampling (simple random) technique for this study was to provide everyone an equal opportunity to express their ideas and opinions about the study without any discrimination, hesitation, and bias. 


\section{Data Analysis}

The questionnaire used consisted of closed-ended questions. The analysis of statistical data is presented in the form of tables for each item in the questionnaire. These tables show the sample responses percentages, frequencies, and cumulative percentages.

Table 1

Lifestyle Preference

Pakistani

Frequency

Percentage

Western

36

24

$60 \%$

Total

60

$100 \%$

According to Table 1, $60 \%$ of students prefer PC (Pakistani culture) and $40 \%$ of students prefer WC (Western culture).

Table 2

Dress style preference for casual and formal wear

\begin{tabular}{lcc}
\hline & Frequency & Percentage \\
\cline { 2 - 3 } Shalwar/kameez & 45 & $75 \%$ \\
Pant shirt & 15 & $25 \%$ \\
Total & 60 & $100 \%$ \\
\hline
\end{tabular}

Table 2 depicts that $75 \%$ of students mostly prefer to wear pant shirts and $25 \%$ of students prefer to wear shalwar/kameez.

Table 3

Favorite Food

$\begin{array}{lcc} & \text { Frequency } & \text { Percentage } \\ \text { Pakistani Food } & 20 & 33 \% \\ \text { Chinese } & 10 & 17 \% \\ \text { Total } & 60 & 100 \%\end{array}$

$50 \%$ of students nowadays want to eat fast food, while $33 \%$ of students like to eat Pakistani food and $17 \%$ prefer Chinese food. Fast food is becoming popular among youngsters.

Table 4

English learning affecting cultural identity

\begin{tabular}{lcc}
\hline & Frequency & Percentage \\
\hline Yes & 40 & $67 \%$ \\
No & 20 & $33 \%$ \\
Total & 60 & $100 \%$ \\
\hline
\end{tabular}

$67 \%$ of students believe that learning EL (English language) affects their CL (cultural identity), 33\% of students believe that learning EL (English language) has not affected their CL (cultural identity).

Table 5

Kind of novels one likes to study

\begin{tabular}{lcc}
\hline & Frequency & Percentage \\
\hline English Novels & 48 & $80 \%$ \\
Urdu Novels & 12 & $20 \%$ \\
Total & 60 & $100 \%$ \\
\hline $80 \%$ of
\end{tabular}

$80 \%$ of students like to read English novels while $20 \%$ of students like to read Urdu novels.

Table 6

Appealing Culture

\begin{tabular}{lcc}
\hline & Frequency & Percentage \\
\hline Pakistani & 16 & $27 \%$ \\
Western & 12 & $20 \%$ \\
Both & 32 & $53 \%$ \\
Total & $60 \%$ & $100 \%$ \\
\hline
\end{tabular}

$53 \%$ of students find both PC (Pakistani culture) and WC (western culture) appealing, while $27 \%$ of students find PC (Pakistani culture) and $20 \%$ find WC (western culture) more appealing. 
Table 7

English language pronunciation affects native language (Urdu) pronunciation

\begin{tabular}{lcc}
\hline & Frequency & Percentage \\
\hline Yes & 24 & $40 \%$ \\
No & 36 & $60 \%$ \\
Total & 60 & $100 \%$ \\
\hline
\end{tabular}

$56 \%$ of students disagree that their Urdu pronunciation is affected due to their English pronunciation while $44 \%$ of students agree that their Urdu pronunciation is being affected due to their English pronunciation.

\section{Table 8}

Studying English changed opinion about the western world

\begin{tabular}{lcc}
\hline & Frequency & Percentage \\
\hline Yes & 21 & $44 \%$ \\
No & 39 & $56 \%$ \\
Total & 60 & $100 \%$ \\
\hline
\end{tabular}

$\mathbf{5 6 \%}$ of students agreed that learning EL (English language) has changed their opinion about the western world while $44 \%$ of students don't agree that learning English has changed their opinion about the western world.

\section{Table 9}

Interested in a course of western culture along with English language course

\begin{tabular}{lcc}
\hline & Frequency & Percentage \\
\hline Yes & 43 & $72 \%$ \\
No & 17 & $28 \%$ \\
Total & 60 & $100 \%$ \\
\hline
\end{tabular}

$72 \%$ of students are interested to learn about western culture as a part of an English course while 36\% of students don't agree with that. They are not interested to learn about western culture as a part of an English course.

Table 10

All Pakistani should learn the English language

\begin{tabular}{ccc}
\hline & Frequency & Percentage \\
\hline Yes & 32 & $53 \%$ \\
No & 28 & $47 \%$ \\
Total & 60 & 100 \\
\hline $53 \%$ of
\end{tabular}

$53 \%$ of students want everyone in Pakistan to learn EL (English language) while 33\% of students do not think that everyone in Pakistan should learn EL (English language).

Table 11

Speaking English Language makes you more modern

\begin{tabular}{lcc}
\hline & Frequency & Percentage \\
\hline Yes & 41 & $68 \%$ \\
No & 19 & $32 \%$ \\
Total & 60 & $100 \%$
\end{tabular}

$68 \%$ of students believe that speaking English makes they look more modern and stylish while $32 \%$ of students do not think that speaking English makes they look stylish or modern.

Table 12

Preferred living place

\begin{tabular}{lcc}
\hline & Frequency & Percentage \\
\hline Pakistan & 35 & 58 \\
Abroad & 25 & $42 \%$ \\
Total & 60 & $100 \%$ \\
\hline
\end{tabular}

$58 \%$ of students still like to live in Pakistan while $42 \%$ of students want to live abroad if they have been given a chance. 
Table 13

Got insulted by English language teachers due to mispronunciation of English words

\begin{tabular}{ccc}
\hline & Frequency & Percentage \\
\hline Yes & 14 & $2 \%$ \\
No & 56 & $98 \%$ \\
Total & 60 & $100 \%$ \\
\hline
\end{tabular}

$98 \%$ of students get not feel insulted by English language teachers due to mispronunciation of English words while $2 \%$ of students feel insulted.

Table 14

First thinking is in Urdu before speaking in English

\begin{tabular}{lcc}
\hline & Frequency & Percentage \\
\hline Yes & 54 & $92 \%$ \\
No & 6 & $8 \%$ \\
Total & 60 & $100 \%$ \\
\hline
\end{tabular}

92\% of students first think in Urdu before speaking in English while $8 \%$ of students don't think in Urdu before speaking English.

Table 15

Preference to speak English in casual or informal life

\begin{tabular}{lcc}
\hline & Frequency & Percentage \\
\hline Always & 49 & $70 \%$ \\
Never & 14.7 & $91 \%$ \\
Sometimes & 6.3 & $9 \%$ \\
Total & 60 & $100 \%$ \\
\hline
\end{tabular}

$70 \%$ of students always prefer to speak English in their casual or informal life while $21 \%$ of students never and $9 \%$ of students sometimes prefer to speak English in their casual or informal life.

Table 16

Speaking English increases life status

\begin{tabular}{lcc}
\hline & Frequency & Percentage \\
\hline Yes & 52.3 & $89 \%$ \\
No & 7.7 & $11 \%$ \\
Total & 60 & $100 \%$ \\
\hline
\end{tabular}

$89 \%$ of students feel speaking English increases one life status while 11\% of students don't feel that speaking English increase one life status.

Conclusions

After inspecting all the results of this study, the surveys, it can without much of a stretch be inferred that the viewpoints and perspectives of the learners have been firmly influenced by their insight into the EL (English language). It appears to be that when they begin finding out increasingly English, the measure of data accessible to them consistently changes. This has allowed them the occasion to get familiar with the world and increment their insight. Before starting the discussion about language and its relation with students, we need to discuss student's attitudes first. Pakistan nowadays is growing towards learning the English language. Since the beginning youngsters are pushed by their folks towards learning the English language, similar to the English language is their lone key to progress. Such weight towards learning English has led to a profoundly mechanical, test-based assessment of progress in language learning. This sort of demeanor towards the English language, which runs over unmistakably is the outcomes gotten through the polls. The English language is viewed as an instrument towards a superior future; better positions, more cash gaining, or conceivably moving to another country. The instrumental disposition towards the English language is exhibited by the witnesses of this investigation while responding to an inquiry that managed the normal impacts of learning the English language on their lives. Lifestyle integral shows everyone's standard of living. Every Pakistani citizen has a different way of living. They speak different languages; dress up following their culture and the variety of food makes them unique to others. According to the survey, $60 \%$ of secondary school students prefer the Pakistani lifestyle and $40 \%$ of the secondary school students prefer the western lifestyle. So, the western lifestyle is also getting popularity but still, most secondary level students prefer the Eastern way of living. 
Dressing means the act of how one dresses him/herself (Reference). Dressing is of two types (informal dressing) or outside (formal dressing). The data analysis clarifies that $75 \%$ of students prefer wearing pant shirt on daily basis and $25 \%$ of students prefer wearing shalwar kameez. So, a majority of students prefer the western style of clothing. 50\% of students like to eat fast food and 33 $\%$ Pakistani food and $17 \%$ Chinese food. So it means students have been influenced by the western food.

Reading is a good habit for students; reading is a great habit for everyone especially for students because it broadens their knowledge and skills. 80\% of students like to read English novels and $17 \%$ like to read Urdu novels and 3\% do not read novels. Pakistan is very rich in literature and history but the majority of students nowadays do not like to read Urdu literature.

The result of the study indicates that $27 \%$ of students feel western culture looks more appealing to them while 20\% like PC (Pakistani culture) and 53\% find both western and PC (Pakistani culture) appealing.

Pronunciation is how a word or language is spoken. The data analysis signifies that $40 \%$ of students feel that due to learning EL (English language) their native language pronunciation is being affected and $60 \%$ feel that leaning EL (English language) is not affecting their native language pronunciation. The differences are not that big between the two opinions but still, students feel that EL (English language) is affecting their native language pronunciation.

Students want to learn about the WC (western culture) as a part of their EL (English language) course. $72 \%$ of students say that they want to learn WC (western culture) while learning EL (English language) and 28\% do not want to learn WC (western culture) as a part of learning EL (English language).

People usually think in that language in which they are fluent. $92 \%$ of students say that they build their thoughts in Urdu and then speak in English and 8\% of students think in English and then speak in English. Most people talk in Urdu at their homes in Pakistan as it is the national language. So students feel confident about the Urdu language. English language is a must in private sector schools and students have to speak it but do they prefer to speak English in their casual or informal meetings. 70\% of students always speak English in their causal or informal meetings, 21\% of students never use the English language and 9\% of the students sometimes prefer speaking English in their casual or informal meetings.

\section{Discussion}

Through the communicative process, English Language has brought about an enormous cultural interlink in the modern age along with the role of the educational system it hinges on it almost the entire world. It thus puts relative importance in the cycle of globalization and social integration. Interaction style has significantly accelerated the exchange of world cultures ideas and knowledge. The global era has made communication means much easier and social homogenization much greater. It has globalized countries that process their cultural affiliation by spreading languages and most notably, by defining in the process the hegemony of English. While being criticized for the contradictions that arise due to diversity or being blamed for devaluing other cultural norms and practices, it has a major impact on cultural homogenization in the context of combining knowledge, ideas, and cultures through the effect of information and communication systems, whether digital or actual or vice versa. Therefore, the era of globalization has greatly enhanced the English language's position and its effect on culture, allowing people to come closer to establishing cultural homogenization across boundaries in the diverse set of different cultural backgrounds.

Urdu is the national language of Pakistan. It carries our emotions, ethics, and cultural values. But to lose one's cultural values cannot be heroic in any sense. Kachru (1986), believe that "the English language is a tool of power, domination and elitist identity..." (Ashcroft, 1995, p. 291).

The results of this study allow the researcher to conclude that learning EL (English language) has both negative and positive effects on the learners and the same has been expressed by (Li, 2020). If you want to talk to someone from another country, you're likely to learn the EL (English Language). At the point when kids first join the school, they accompany their local societies, yet the vast majority of them would have overlooked their local language and culture when they leave school which is mentioned by Seidlhofer (2005). Youngsters invest the vast majority of their energy in school and English is the official language for second language understudies specifically. The way that their local dialects are not permitted to be utilized in schools makes it hard for them to 
comprehend their noteworthiness. The view of the local dialects is negative to the point that the understudies take a gander at it in a corrupting and troublesome manner.

\section{Recommendations}

As language is what contains culture; there is no identity for a person without a language. The learning of EL (English Language) has therefore contributed greatly to the loss of the second English language acquirer's CI (cultural identity). The teachers of the English language may make a deliberate effort to sensitive learners to minimize the effects of language on their identity.

\section{References}

Ahad, A. M. (2014). The Effect of Language Changes on Culture Cause by Producing Knowledge and Technology. SciPress, 5.

Barber, S. (2013). The influence of culture and identity on second language acquisition: a perspective from Egypt.

G. (2013). Conscious Reconstruction: The Effects of Second Language Acquisition on SelfPerception of Gender Identity.

Hatoss, A. (2003). Identity formation, cross-cultural attitudes and language maintenance in the Hungarian Diaspora of Queensland. Cultural Citizenship: Challenges of Globalization. Decan University, Melbourne, 71-77.

Johnson, A. (2009). The rise of English: The language of globalization in China and the European Union. Macalester International, 22(1), 12.

Jafari, T. S. (2012). Language and Culture. International Journal of Humanities and Social Science, 6.

Kumagai, Y. (1994). The Effects of Culture on Language Learning and Ways of Communication: The Japanese Case. Master's Capstone Projects,

Kanno, Y., \& Varghese, M. M. (2010). Immigrant and refugee ESL students' challenges to accessing four-year college education: From language policy to educational policy. Journal of Language, Identity, and Education, 9(5), 310-328.

Li, C. (2020). A positive psychology perspective on Chinese EFL students' trait emotional intelligence, foreign language enjoyment, and EFL learning achievement. Journal of Multilingual and Multicultural Development, 41(3), 246-263.

Lobatón, J. C. G. (2012). Language learners' identities in EFL settings: resistance and power through discourse Las identidades de estudiantes de inglés Como Lengua extranjera: Resistencia y poder discursivo.

Mahboob, A. (2003). The English language in Pakistan: a brief overview of its history and linguistics. Pakistan Journal of Languages, 48.

Ms. Sana Nawaz, M. A. (2012). Language and Culture. Double-Blind Peer Reviewed International Research Journal, 7.

Nabi, A. (2017). Language and Culture. IOSR Journal of Humanities and Social Science,

Ochs, E. (1993). Constructing Social Identity: A Language Socialization Perspective. California: Lawrence Eribaum Associates.

Owen, C. (2011). Language and cultural identity: Perceptions of the role of language in the construction of Aboriginal identities. 197.

Poggensee, A. (2016). The effects of globalization on English language learning: Perspectives from Senegal and the United States.

Razmeh, S. (2015). Identity and Culture Shaped by Foreign Language Learning: A Case of Iranian University Students. 70.

Ricento, T. (2002). Considerations of Identity in L2 Learning. 16.

Rodrigues, A. (2017). Linguistic Patterns and Linguistic Styles. European Conference, (p. 27).

Seidlhofer, B. (2013). Oxford Applied Linguistics: Understanding English as a Lingua Franca. Oxford University Press.

Seppälä, M. (2011). The effects of the English language on the cultural identity of Chinese university students.

Seidlhofer, B. (2005). English as a lingua franca. ELT Journal Volume, 3.

Shamim, F. (2005). English as the language for development in Pakistan. English for development in Pakistan, 16.

Wyatt, A. (2009). Identity, Language, and Culture in Eva Hoffman's Lost in Translation. 